\title{
IMPLEMENTASI PERATURAN BUPATI GUNUNGKIDUL NOMOR 36 TAHUN 2015 TENTANG PENCEGAHAN PERKAWINAN PADA USIA ANAK DALAM PERSPEKTIF MASLAHAH MURSALAH
}

\author{
Muhammad Agung Ilham Affarudin \\ Fakultas Syariah dan Hukum UIN Sunan Ampel Surabaya \\ Email: agungilham45@gmail.com \\ Nurul Asiya Nadhifah \\ Fakultas Syariah dan Hukum UIN Sunan Ampel Surabaya \\ Email: nurulasiya@uinsby.ac.id
}

\begin{abstract}
Regent Regulations (Perbup) of Gunungkidul Number 36 Year 2015 Concerning Prevention of Marriage at the Age of Child is a special regulation regarding the efforts, programs, actions, activities used by the government agencies of Gunungkidul Regency in order to prevent and reduce the number of marriages at the age of child. Wonosari Religious Court statistics show a decrease in the number of submissions for marriage dispensations from 2015 to 2017 after the enactment of this regulation. In 2015 there were 109 cases of marriage dispensation, in 2016 there were 85 cases of marriage dispensation, in 2017 there were 65 cases of marriage dispensation. In its implementation, this regulation has benefits because it forms the basis of buman life (maslahah dharuriyyah). This regulation has also answered the problems that humans need to eliminate the difficulties they face (maslabah hajiyyah). In addition, this regulation has preserved the wisdom and goodness of manners and social and cultural beauty (maslahah tabsiniyyah). Seen from its implementation, Perbup Gunungkidul Number 36 of 2015 concerning Prevention of Marriage at the Age of Child is in accordance with the principles of problem solving.
\end{abstract}

Keywords: Prevention of Marriage, Maslabah Mursalah, Child Age Marriage

Abstrak: Implementasi Perbup Gunungkidul Nomor 36 Tahun 2015 Tentang Pencegahan Perkawinan Pada Usia Anak merupakan peraturan khusus berupa upaya-upaya, program, aksi, kegiatan yang digunakan instansi pemerintahan Kabupaten Gunungkidul dalam rangka mencegah terjadinya perkawinan pada usia anak dan menurunkan angka perkawinan pada usia anak. Peraturan ini memiliki sisi kebaikan dan kemanfaatan dimana peraturan ini memang telah menjadi dasar tegaknya kehidupan asasi manusia (maslahah dharuriyyah), peraturan ini juga telah menjawab persoalan yang dibutuhkan manusia untuk menghilangkan kesulitan dan kesusahan yang dihadapi (maslahah bajiyyah), selain itu peraturan ini telah

AL-HUKAMA

The Indonesian Journal of Islamic Family Law Volume 09, Nomor 01, Juni 2019; ISSN:2089-7480 
Muhammad Agung: Implementasi Peraturan Bupati......

memelihara kebagusan dan kebaikan budi pekerti serta keindahan sosial budaya (maslahah tabsiniyyah). Sesuai dengan penelitian ini maka Perbup Gunungkidul Nomor 36 Tahun 2015 Tentang Pencegahan Perkawinan Pada Usia Anak telah sesuai dengan prinsip-prinsip maslahah mursalah. Oleh sebab itu, maka disarankan peraturan ini bisa dijadikan percontohan untuk ditiru dan diterapkan oleh daerah di sekitarnya baik secara skala dalam provinsi maupun skala luar provinsi se-Indonesia.

Kata Kunci: pencegahan pekawinan, maslahah mursalah, usia anak

\section{Pendahuluan}

Anak merupakan karunia dan amanah Allah SW'T yang harus senantiasa dilindungi karena dalam diri anak melekat harkat, martabat, dan hak-hak sebagai manusia yang harus dijunjung tinggi.1 Ditinjau dari aspek yuridis; pengertian "anak" dalam hukum positif Indonesia lazim diartikan sebagai orang yang belum dewasa, orang yang dibawah umur atau keadaan di bawah umur, atau kerap juga disebut sebagai anak yang dibawah pengawasan wali.2

Anak ialah insan pribadi (persoon) yang memiliki dimensi khusus dalam kehidupannya, dimana selain tumbuh kembangnya memerlukan bantuan orang tua, faktor lingkungan juga memiliki peranan yang sangat penting dalam mempengaruhi kepribadian si anak ketika menyongsong fase kedewasaannya kelak. 3

Terminologi lain dari Undang-undang tentang anak juga sering disebutkan; mulai dari anak merupakan amanah sekaligus karunia Tuhan yang Maha Esa, anak memiliki potensi serta sebagai penerus cita-cita bangsa, anak menjadi bagian dari generasi muda yang memiliki peranan strategis dan mempunyai ciri serta sifat khusus, dan anak sebagai aset sumber daya manusia yang berperan bagi pembangunan nasional.4

Anak adalah sosok yang akan memikul tanggung jawab di masa yang akan datang. Anak juga manusia, dan karenanya menghormati hak asasi anak sama halnya dengan menghormai hak

1 Sutomo, et al., Menggugat Stagnasi Pembaruan Hukum Islam di Indonesia, (Yogyakarta: UII Press, 2016), 299.

2 Ibid., 299.

3 Witanto, Hukum Keluarga Hak dan Kedudukan Anak Luar Kawin Pasca Keluarnya Putusan MK Tenang Uji Materiil UU Perkawinan, (Jakarta: Prestasi Pustaka, 2012), 4.

${ }^{4}$ Ibid., 5. 
asasi manusia (HAM)5, sehingga tidak berlebihan jika negara memberikan suatu perlindungan bagi anak-anak dari perlakuanperlakuan yang dapat menghancurkan masa depannya.

Pada umumnya orang tua berharap kelak seorang anak akan mampu mewujudkan harapan dan cita-citanya yang belum tercapai, disisi lain anak juga akan menjadi pewaris dari harta dan kekayaan yang ditinggalkan orang tuanya kelak jika ia meninggal. Namun pada faktanya, problematika pernikahan dini atau yang sering disebut pernikahan dilakukan oleh kedua calon mempelai pengantin atau salah satunya, baik pria maupun wanita yang masih belum memenuhi kedewasaan umur dalam angka menurut undangundang, menjadikan cerminan yang paling fundamental sebagai tolak ukur terwujudnya cita-cita orang tuanya.

Isu perkawinan anak dibawah umur yang ramai dibicarakan pada zaman milenial belakangan ini merupakan diskursus kompleks yang bersinggungan dengan beragam aspek, mulai dari hukum, agama, adat, ekonomi, sosial, hingga kesehatan. Terkait dengan polemik hukum, perkawinan anak dibawah umur itu bertabrakan secara diametral dengan ketentuan hukum yang menetapkan batas usia minimum untuk menikah.

Terkait dengan polemik hukum, perkawinan anak dibawah umur itu bertabrakan secara diametral dengan ketentuan hukum yang menetapkan batas usia minimum untuk menikah.6 Berbeda dengan ranah agama, sebab praktis tradisi yang masih menjarah luas, khususnya kaum santri tradisional, disinyalir kuat isu ini ditampik dengan motif "teologis", artinya justifikasi normatif dari teks agama atau yang disebut fikih itu tidak menetapkan batas usia minimum bagi laki-laki dan perempuan untuk melangsungkan perkawinan.7

Lain lagi jika dilihat dari kacamata adat, yang mengatakan bahwa prakik perkawinan anak dibawah umur itu kerapkali terjadi karena dorongan kultural dalam suatu komunitas yang masih memposisikan anak perempuan sebagai warga kelas dua. Selain persentuhannya dengan aspek-aspek tersebut, perkawinan anak di

5 Yusuf Hanafi, Kontroversi Perkawinan Anak di Bawah Umur Perspektif Fikih Islam, HAM Internasional, dan UU Nasional, (Bandung: Mandar Maju, 2011), 28.

${ }^{6}$ Ibid., ii.

7 Ibid., 28. 
bawah umur juga kental dengan aroma dan motif ekonomi, dimana sering kali alasan ekonomi menjadikan boomerang bagi orang tua untuk menyegerakan anak supaya menikah meskipun usianya masih di bawah umur.8

Dari sudut pandang sosial, maraknya kasus perkawinan anak di bawah umur itu berbanding lurus dengan laju pertambahan penduduk yang dibarengi dengan sosio cultural bahwa menikah muda menjadikan trend bagi si anak. Secara medis berbeda lagi, perkawinan anak di bawah umur yang dikampanyekan oleh PBB sebagai praktik tradisi yang berbahaya, karena akan mendatangkan resiko kesehatan yang tinggi bagi pelakunya.9

Seperti yang telah dijelaskan dari sedikit paparan diatas, menikah itu memang menjadi kebutuhan bagi siapa saja, menikah memberikan warna tersendiri saat menjalani hidup, tidak hanya orang yang dirasa cakap kedewasaannya saja yang boleh menikmati warna itu, sering kali anak juga menuntut bahkan dituntut untuk menggapai warna itu, tapi menikah itu bukan perkara yang mudah seperti membalikkan tangan, dirasa sangat urgentif untuk permasalahan ini sehingga perlu edukasi khusus supaya tujuan menikah itu bisa tercapai.

Dalam Kompilasi Hukum Islam (KHI) Pasal 2 disebutkan bahwa perkawinan menurut hukum Islam adalah akad yang sangat kuat atau mithaqan ghalizan untuk mentaati perintah Allah dan melaksanakannya merupakan ibadah.10 Hal tersebut sesuai dengan Undang-undang Nomor 1 Tahun 1974 tentang Perkawinan (UU Perkawinan) yang menjelaskan bahwa perkawinan adalah ikatan lahir batin antara seorang pria dengan seorang wanita sebagai suami isteri dengan tujuan membentuk keluarga atau rumah tangga yang bahagia berdasarkan Ketuhanan Yang Maha Esa.11

Setiap perbuatan hukum tentu ada dasarnya, termasuk juga masalah perkawinan ini. Perkawinan mempunyai peranan penting

8 Ibid., 28.

9 Ibid., 29.

10 Abdurrahman, Kompilasi Hukum Islam di Indonesia cet ke-4 (Jakarta: Akademia Pressindo, 2010), 22.

11 Kementerian Agama RI, "UU Nomor 1 Tahun 1974 tentang Perkawinan", dalam https://kemenag.go.id-file-dokumen, diakses pada 22 Oktober 2018. 
bagi manusia dalam hidup dan perkembangannya. Untuk itu, Allah Swt., melalui utusannya memberikan suatu tuntunan mengenai perkawinan ini sebagai dasar hukum.12 Adapun dasar hukum perkawinan dalam Islam adalah firman Allah Swt dalam Al-Quran, salah satu diantaranya yakni surat Ar-Rum ayat 21:

"Dan di antara tanda-tanda kekuasaan-Nya ialah Dia menciptakan untukmu isteri-isteri dari jenismu sendiri, supaya kamu cenderung dan merasa tenteram kepadanya, dan dijadikan-Nya diantaramu rasa kasib dan sayang. Sesunggubnya pada yang demikian itu benar-benar terdapat tanda-tanda bagi kaum yang berfikir."13

Selain ayat al-Qur'an di atas, ada beberapa hadits Nabi saw yang berisi anjuran-anjuran perkawinan. Diantaranya adalah anjuran perkawinan bagi orang-orang yang telah dianggap mampu mempunyai kesanggupan memelihara diri dari kemungkinankemungkinan melakukan perbuatan yang tercela (terlarang), maka perkawinan lebih baik baginya. Sabda Nabi saw dalam hadist riwayat Al-Bukhari yang artinya:

"Wahai para pemuda, barang siapa yang mampu diantara kalian untuk menikahi perempuan, maka menikahlah. Dan barang siapa yang belum mampu, maka hendaklah ia melakukan bepuasa, karena berpuasa itu adalah penekan nafsu syahwat bagi dirinya." 14

Pada dasarnya Islam tidak pernah memberikan peraturan yang tegas mengenai batasan usia menikah, jika ditelisik lebih jauh pernikahan Rasulullah saw dengan Aisyah ra seringkali dijadikan percontohan masyarakat Indonesia yang berpedoman pada fikih klasik, mereka beranggapan yang terpenting adalah kedua calon mempelai harus sudah akil baligh secara biologis, yakni laki-laki yang

12 Nasiri, Kapita Selekta Perkawinan, (Cilacap: Ihya Media, 2016), 12.

13 Departemen Agama Republik Indonesia, Al-Qur'an dan Terjemahannya (Jakarta:

Toha Putra Semarang, 1989), 115.

15 Sjarief Sukandy, Tarjamah Bulughul Maram (Bandung: Al-Ma'arif, 1995), 356. 
ditandai dengan mimpi basah15, sedangkan perempuan ditandai dengan menstruasi.16

Dari dalil diatas, dapat kita ketahui bahwasanya menikah memiliki beberapa tujuan yang diantaranya; merupakan satu bentuk kebesaran Allah, menjadi satu wadah taqarrub kepada Allah, mewujudkan kehidupan rumah tangga yang sakinah, mawaddah, warahmah, memenuhi kebutuhan biologis, memiliki keturunan, dan tentu masih banyak sekali tujuan yang tersirat. Maka, sangat dianjurkan bagi kaum muslimin untuk hendak menyegarakan menikah, supaya bisa terhindar dai hal-hal yang tercela.17

Bagaimana dengan peraturan di Indonesia sendiri mengenai pernikahan dini? Disebutkan bahwa dalam Pasal 7 ayat1 Undangundang Nomor 1 Tahun 1974 tentang Perkawinan bahwa perkawinan hanya diizinkan jika pihak pria telah mencapai umur 19 tahun dan pihak wanita sudah berusia 16 tahun. Penyimpangan terhadap ketentuan usia kawin ini dapat dimintakan dispensasi kepada Pengadilan atau pejabat lain yang ditunjuk oleh kedua orang tua dari pihak pria maupun pihak wanita.

Kompilasi Hukum Islam (KHI), yang disebarluaskan melalui Inpres Nomor 1 Tahun 1991, memuat perihal yang kurang lebih sama. Pada pasal 15 KHI menyebutkan bahwa batas usia perkawinan sama seperti pasal 7 Undang-undang No 1 Tahun 1974, namun dengan tambahan alasan untuk kemaslahatan keluarga dan

17 Yaitu mimpi yang disertai keluarnya air mani dari alat kemaluannya. Peristiwa ini juga disebut dengan istilah ihtilām., yang biasanya terjadi pada laki-laki usia antara 12-15 tahun. Selain itu, laki-laki baligh juga akan mengalami tumbuhnya alat-alat seksual sekunder di sekitar alat kelamin, yakni rambut kemaluan dan adanya pembesaran suara. Ahmad Arif Masdar Hilmy, 2018, Analisis Terbadap Perbedaan Batas Usia Minimal Perkawinan Dalam Pasal 15 Kompilasi Hukum Islam (KHI) Perspektif Teori Maslabah Sa’id Ramadan Al-Buti, (Skripsi -- UIN Sunan Ampel, Surabaya, 2018), lihat Rahmat Sudirman, Konstruksi Seksualitas Islam dalam Wacana Sosial (Yogyakarta: Media Pressindo, 1999), 34.

18 (Haid adalah darah yang dikeluarkan dari rahim seorang wanita setelah ia sampai pada waktu tertentu. Peristiwa ini biasanya dialami wanita pada usia antara 9-15 tahun. Wanita yang sudah memasuki usia baligh juga akan mengalami pertumbuhan organ-organ seksual sekunder seperti pembesaran payudara, pembesaran daerah pinggul dan tumbuhnya rambut di sekitar alat kemaluan. Ahmad Arif Masdar Hilmy, (Skripsi -- UIN Sunan Ampel, Surabaya, 2018).

${ }^{16}$ Nasiri, Kapita Selekta Perkawinan, 23. 
rumah tangga. Maka, secara eksplisit tidak tercantum jelas larangan untuk menikah di bawah umur. Penyimpangan terhadapnya dimungkinkan dengan adanya izin dari pengadilan atau pejabat lain yang berkompeten. Dari sini terlihat jelas bahwa tidak ada satupun larangan yang mencegah anak di bawah umur yang hendak menikah demi terwujudnya tujuan pernikahan itu sendiri.18

Lain halnya dengan apa yang peneliti temukan di Indonesia tepatnya daerah Gunungkidul Yogyakarta. Pada daerah ini terdapat peraturan unik yang ditujukan kepada masyarakatnya, ditemukan bahwa jumlah perkawinan pada usia anak di Gunungkidul menunjukkan angka yang kian hari kian meninggi, dan dari perkawinan pada usia di bawah umur tersebut mengakibatkan pada kesehatan ibu dan anak, psikologis anak, terjadinya kekerasan dalam rumah tangga, kemiskinan dan rendahnya kualitas sumber daya manusia, karena itu perlu upaya-upaya pencegahan terjadinya perkawinan pada usia di bawah umur dalam rangka perlindungan anak, dalam upaya pencegahan perkawinan pada usia di bawah umur ini dirasa akan berjalan secara efektif dan optimal jika ada aturan yang mengikat, sehingga lahirlah Peraturan Bupati Nomor 36 Tahun 2015 tentang Pencegahan Perkawinan Pada Usia Anak.

\section{Maslahah Mursalah}

Maslahab Mursalab terdiri dari dua kata, yaitu maslabah dan mursalah. Kata maslahah menurut bahasa berarti manfaat, dan kata mursalah berarti lepas19. Secara etimologis, kata المصاي لمصلحة jamaknya berarti sesuatu yang baik, yang bermanfaat, dan ia merupakan lawan dari keburukan dan di dalam bahasa Arab sering pula disebut dengan yaitu yang baik dan yang benar.20

Pengertian lain maslahah dalam bahasa arab adalah perbuatanperbuatan yang mendorong kepada kebaikan manusia. Dalam arti yang umum adalah setiap segala sesuatu yang bermanfaat bagi manusia, baik dalam arti menarik atau menghasilkan seperti menghasilkan keuntungan (kesenangan), atau dalam arti menolak

18 Ibid., 29.

20 Romli SA, Pengantar Ilmu Usul Fiqih Metodologi Penetapan Hukum Islam, (Depok: Kencana, 2017), 188. 
atau menghindarkan seperti menolak kerusakan.21 Sedang kata mursalah artinya sesuatu yang baik, patut, dan bermanfaat.22

Dalam qawa'id al-fiqiyah, maslahah sendiri juga memiliki cabangnya, yakni:

$$
\text { تصرف الامام على الرعية منوط بالمصلح }
$$

"Kebijaksanaan Imam/kepala Negara terhadap rakyat itu harus dihubungkan dengan kemalahatan"

Kaidah ini memberikan pengertian, bahwa setiap tindakan atau kebijaksanaan para pemimpin yang menyangkut dan mengenai hak-hak rakyat dikaitkan dengan kemaslahatan rajyat banyak dan ditujukan untuk mendaangkan suatu kebaikan.23

\section{Syarat-syarat Maslahah Mursalah}

Romli mengutip buku Usul al-Fiqh al-Islami karya Zaky Al-Din Sya'ban menyebutkan syarat yang harus diperhatikan bila menggunakan Maslahab Mursalah dalam menetapkan hukum:24

1. Kemaslahatan itu hendaknya kemaslahatan yang memang tidak terdapat dalil yang menolaknya.

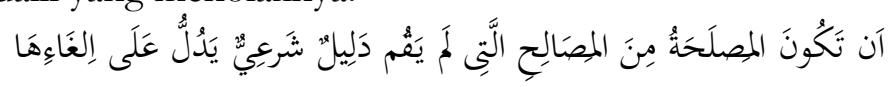

Dengan kata lain, jika terdapat dalil yang menolaknya tidak dapat diamalkan. Hakikat mursalah itu sama sekali tidak ada dalam nas, baik yang menolak maupun yang mengakuinya, tetapi terdapat kemaslahatan yang dihajatkan oleh manusia yang keberadaannya sejalan dengan tujuan syara'. Romli mengutip Abdul Karim Zaidan dan Muhammad Abu Zahrah menyebutnya dengan maslahah yang sesuai dengan tujuan syara' Sementara itu Jalaluddin Abdurrahman menyebutkan bahwa hendaklah Maslahab itu menyangkut hal-hal yang bersifat daruri. Maksudnya, disyaratkan bahwa maslabah itu untuk memelihara persoalan yang

21 Totok Jumantoro, Kamus Ilmu Usul Fikih, (Jakarta: Sinar Grafika Offset, 2005), 200.

22 Muhammad Yunus, Kamus Arab Indonesia, (Jakarta: Yayasan Penyelenggaraan Penerjemah dan Penafsir al-Quran, 1973), 219.

23 Imam Musbikin, Qawa'id al Fiqhiyyah, (Jakarta: RajaGrafindo Persada, 2001), 124.

24 Ibid., 199-202. 
daruri seperti berkaitan dengan terpeliharanya agama, jiwa, harta, keturunan, dan akal.

2. Maslahah mursalah itu hendaklah maslahah yang dapat dipastikan bukan hal yang samar-samar atau perkiraan dan rekayasa saja.

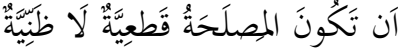

Romli mengutip Zaky Al-Din Syaban, disyaratkan bahwa maslahat Mursalab itu bukan berdasarkan keinginan saja, karena hal yang demikian tidak dapat diamalkan.

3. Maslabah mursalab hendaklah maslahat yang bersifat umum, yang dimaksud dengan maslahah yang berlaku umum ini adalah kemaslahatan yang memang terkait dengan kepentingan orang banyak.

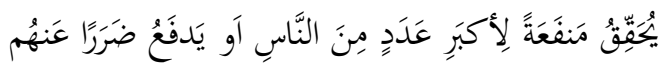

Maslahat Mursalah itu hendaklah dapat merealisasi kepentingan orang banyak dan menghindari mereka dari kerusakan.

4. Selain pada sumber yang sama disebutkan ada syarat lain dari maslabah mursalab yaitu hendaklah kemaslahatan yang logis dan cocok dengan akal.

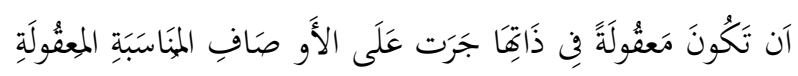

Maslahah Mursalah tersebut hendaklah maslahat yang esensinya logis yang didasarkan pada sifat-sifat yang sesuai dan rasional.

Maksudnya, secara substansial maslahah itu sejalan dan dapat diterima oleh akal.

5. Kemudian Romli mengutip pada Imam Al-Ghazali, sebagaimana dikutip oleh Jalaluddin Abdurrahman menyebutkan bahwa maslahah mursalab hendaklah Maslabah yang disepakati oleh orangorang Islam tentang keberadaanya dan terbukti dipraktikkan dalam kehidupan mereka.

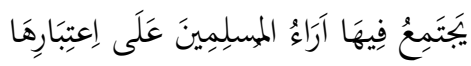

Maslahah tersebut hendaklah disepakati (tidak ada pertentangan) atas keberadaannya di kalangan umat Islam.

\section{Macam-macam Maslahah Mursalah}


Dilihat dari segi pembagian, maslahah dapat dibedakan menjadi dua macam25 yaitu:

1. Maslahab dari segi tingkatannya

Yang dimaksud dengan macam maslahah dari segi tingkatannya ialah berkaitan dengan kepentingan yang menjadi hajat hidup manusia. Romli mengutip Mustafa Said Al-Khind pada bukunya yang berjudul Athar Al-Ikbtilaf Fi Al-Qawaid AlUsuliyah Fi Ikbtilaf Al-Fuqaha maslahah dilihat dari segi tingkatannya ini dapat dibedakan menjadi tiga macam, yakni:

a. Maslahah Daruriyyah (المصالح الضرورية)

Yang disebut dengan maslabah pada tingkatan ini ialah kemaslahatan yang menjadi dasar tegaknya kehidupan asasi manusia yang berkaitan dengan agama maupun dunia. Jika ia luput dalam kehidupan manusia, maka mengakibakan rusaknya tatanan kehidupan manusia.

Maslahah daruriyyah itu adalah menyangkut kepentingan asasi yang sangat bernilai, ia menyangkut persoalan-persoalan untuk terciptanya kelangsungan hidup manusia, jika ia terganggu maka cederalah dan terganggulah kelangsungan hidup yang akan mengakibatkan timulnya kerusakan (fitnah) dan bencana yang besar secara luas.

Maslahah daruriyyah dishariatkan untuk melindungi dan menjamin kelestarian agama (bifz al-din), melindungi jiwa (hifz al-nafs), melindungi akal (bifz al-aq), melindungi keturunan (bifz al-nash), dan melindungi harta (bifzal-mal).

Untuk melidungi agama Allah mensyariatkan bermacam-macam ibadah, mengharamkan murtad, melarang memakai sesembahan selain Allah dan lain-lain. Untuk melindungi jiwa, Allah melarang pembunuhan, melarang segala tindakan yang membahayakn jiwa, mensyariakan pernikahan, mewajibkan mencari rizki dan lain-lain. Untuk nmelindungi akal, Allah mengharamkan meminum minuman keras, mewajibkan menuntut ilmu dan lain-lain. Untuk melidungi keturunan, Allah mesyariatkan pernikahan, 
melarang perzinahan dan lain-lain. Sedang untuk melindungi harta, Allah mengharamkan pencurian, riba, judi, dan lain-lain.

b. Maslahah Hajizyah (المصاح الحاجية)

Yang dimaksud dengan maslahah hajiyyah jenis ini ialah persoalan-persoalan yang dibutuhkan oleh manusia untuk menghilangkan kesulitan dan kesusahan yang dihadapi. Dengan kata lain, maslahab ini lebih rendah tingkatannya dari maslabah daruriyyah. Dalam rangka merealisasikan maslahah bajiyyah ini Allah mensyariatkan berbagai transaksi, sepert jual beli, sewa menyewa, dan memberikan beberapa keringanan (rukhsah), seperti kebolehan menjamak dan menqashar shalat bagi musafir, kebolehan menunda pelaksanaan berpuasa ramadhan bagi orang yang sedang hamil, menyusui dan sakit, seerta tidak diwajibkannya shalat lima waku bagi orang yang sedang haid dan nifas.

c. Maslahab Tahsiniyyah (المصالح التحسينية)

Maslahab ini sering disebut dengan maslahah takmiliyah, yang dimaksud dengan maslahah jenis ini ialah sifatnya untuk memelihara kebagusan dan kebaikan budi pekerti serta keindahan saja. Dengan kata lain, maslahah ini lebih rendah tingkatannya dari maslahah daruriyyah. Dalam rangka merealisasikan maslahah bajiyyah ini Allah mensyariatkan berbagai transaksi, sepert jual beli, sewa menyewa, dan memberikan beberapa keringanan (rukhsah), seperti kebolehan menjamak dan menqashar shalat bagi musafir, kebolehan menunda pelaksanaan berpuasa ramadhan bagi orang yang sedang hamil, menyusui dan sakit, seerta tidak diwajibkannya shalat lima waku bagi orang yang sedang haid dan nifas.

Kesemua maslahah yang dikategorikan kepada maslabah tabsiniyyah ini, sifatnya hanya untuk kebaikan dan kesempurnaan. Sekiranya tidak dapat diwujudkan dan dicapai oleh manusia tidaklah sampai menyulitkan dan merusak tatanan kehidupan mereka, tetapi ia dipandang penting dan dibutuhkan.26

26 Romli SA, Pengantar Ilmu Usul Fiqih, 194 
Dari pembagian maslabah dilihat dari segit tingkatannya ini, ternyata secara substansial maslahah dapat dibedakan, tentu saja dalam praktiknya dan usaha untuk mewujudkannya dalam kehidupan ini bisa saja terjadi benturan diantara ketiga bentuk maslabah yang disebutkan tadi. Jika terjadi benturan dua kemaslahatan seperti antara maslahah daruriyyah dengan maslahah bajiyyah, maka maslahah daruriyyah harus didahulukan. Sebab maslahah daruriyyah menyangkut sektor penting yang paling asasi dalam kehidupan (نظام الحياة) yang tidak bisa ditawartawar. Jika ia terganggu dan tidak dilindungi, maka akan mengakibatkan rusaknya tatanan kehidupan manusia. Berbeda hal nya dengan maslahah hajizyah, ia memang penting dan dibutuhkan dan harus dipelihara, tetapi jika tidak dapat mewujudkan dalam kehidupan, hanya menimbulkan kesulitan saja bagi manusia dan tidak sampai pada rusaknya kehidupan.27

Demikian juga halnya antara maslabah hajiyyah dengan maslabah tabsiniyyah, maka yang didahulukan adalah maslahah bajiyyah. Sebab, maslahah hajiyyah menempati posisi yang lebih tinggi daripada tabsiniyyah. maslahah tahsiniyyah sifatnya untuk kesempurnaan dan pelengkap saja serta tidak dapat diwujudkan.28

2. Maslabah deri segi eksistensinya

a. Maslahah Mu'tabarah ( المصالح المعتبرة)

Yang dimaksud dengan maslabah jenis ini ialah kemaslahatan yang terdapat nash secara tegas menjelaskan dan mengakui keberadaannya. Dengan kata lain, seperti disebutkan oleh Muhammad al Said Ali Abd Rabuh dalam bukunya yang berjudul Bubus Fi Al-Adillah Al-Mukbtalaf Fiba Inda Usuliyin yang dikutip Romli yaitu kemaslahatan yang diakui oleh syari dan terdapat dalil yang jelas untuk memelihara dan melindunginya.29 


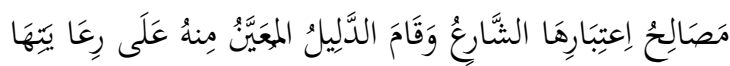

Maslahah mu'tabarah adalah maslahah yang diakui oleh syari keberadaannya dan terdapat dalil (nas) yang menyatakan untuk melindungi dan memeliharanya. 30

Jika syari menyebutkan dalam nash tentang hukum suatu peristiwa dan menyebutkan nilai maslahah yang dikandungnya, maka hal tersebut disebut dengan maslahah mu'tabarah, yang termasuk ke dalam semua maslahah ini ialah semua kemaslahatan yang dijelaskan dan disebutkan oleh nash, seperti memelihara agama, jiwa, keturunan, dan harta benda. Seluruh ulama sepakat bahwa semua maslabah yang dikategorikan maslabah mu'tabarah wajib ditegakkan dala kehidupan, karena dilihat dari segi tingkatan ia merupakan kepentingan pokok yang wajib ditegakkan.31

b. Maslahah Al-Mulghah ( المصالح الملغاة)

Yang dimaksud dengan maslabah ini ialah maslahah yang berlawanan dengan ketentuan nash, dengan kata lain maslabah yang tertolak karena ada dalil yang menunjukkan bahwa ia bertentangan dengan ketentuan dalil yang jelas.32

Contoh yang sering dirujuk dan ditampilkan oleh ulama usul ialah menyamakan pembagian harta warisan antara seorang perempuan dan saudara laki-lakinya. Penyamaan antara seorang perempuan dan saudara laki-laki tentang warisan memang terlihat ada kemaslahatannya, tetapi berlawanan dengan ketentuan dalil nas yang jelas dan terperinci, penyamaan anak laki-laki dan anak perempuan dengan alasan kemaslahatan seperti inilah yang disebut dengan Maslahah mulghah, karena bertentangan dengan nas yang sarih. 33

c. Maslabah Mursalab

Yang dimaksud maslahah mursalab ini ialah maslabah yang secara eksplisit tidak ada satu dalil pun baik yang mengakuinya

30 Ibid., 195.

31 Ibid., 196.

32 Ibid., 196.

33 Ibid., 196 
maupun menolaknya, tetap keberadaannya sejalan dengan tujuan syariat. Secara lebih tegas maslahah mursalah ini termasuk jenis maslabah yang didiamkan oleh nash. Romli mengutip Abdul Karim Zaidan menyebutkan yang dimaksud dengan Maslahah mursalab ialah:34

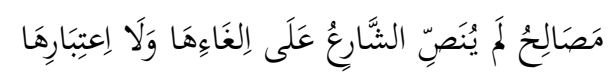

Maslahah mursalah adalah maslahah yang tidak disebutkan oleh nash baik penolakannya maupun pengakuannya.35

Dengan demikian, maslahah mursalah ini merupakan maslahah yang sejalan dengan tujuan syara' yang dapat dijadikan dasar pijakan dalam mewujudkan kebaikan yang dihajatkan oleh manusia serta terhindar dari kemudaratan. 36

Diakui hanya dalam kenyataannya jenis maslabah ini terus tumbuh dan berkembang seiring dengan perkembangan masyarakat Islam yang dipengaruhi oleh perbedaan kondisi dan tempat.37

Menurut Jalaluddin Abdurrahman yang dikutip Romli, bahwa maslahah mursalab ini dapat dibedakan menjadi dua macam: 38

1. Maslahah yang pada dasarnya secara umum sejalan dan sesuai dengan apa yang dibawa oleh syariat.Maslabah yang sesuai dengan apa yang dibawa oleh syari' dan secara umum sejalan dengan cara (metode) yang telah digariskan oleh Allah. Dengan kata lain, kategori maslahah jenis ini berkaitan dengan Maqasid Al-Syariah, yaitu agar terwujudnya tujuan syaria yang bersifat daruri (pokok).

2. Maslabah yang sifatnya samar-samar dan sangat dibutuhkan kesungguhan dan kejelian para mujtahid untuk merealisasinya dalam kehidupan.

\section{Pendapat Ulama Tentang Usia Baligh Pernikahan}

Mengenai batas umur perkawinan, Islam memberikan baasan yang sangat elastis sehingga bisa berlaku bagi semua tempat dan

34 Ibid., 198.

35 Ibid., 198.

36 Ibid., 198.

37 Ibid., 199.

38 Ibid., 199. 
masa. Diantara ayat Alqur'an yang memberikan batasan umur perkawinan yang elastis adalah:

Dan ujilah anak yatim itu sampai mereka cukup umur untuk kawin. Kemudian jika menurut pendapatmu mereka telah cerdas (pandai memelihara harta), maka serabkanlah kepada mereka harta-bartanya.

Ali Wafa mengutip Muhammad Rasyid Rida dalam tafsirnya menyatakan bahwa bulugh al-nikah yang terdapat dalam ayat 6 surat An-Nisa berarti sampainya seseorang pada umur menikah, yakni sampai bermimpi. Pada umur ini seseorang telah bisa melahirkan anak dan telah menurunkan keturunan, sehingga tergerak hatinya untuk menikah. Seperti ibadah dan muamalah serta diterapkannya budud, rushd adalah kepantasan seseorang dalam ber-tasharruf serta mendatangkan kebaikan. Hal ini merupakan bukti kesempurnaan akalnya. Bulugh al-nikah ditandai dengan al-rushd atau kecerdasan dan kecerdikan.

Nabi Muhammad saw melangsungkan akad nikah dengan Aisyah ketika ia baru berusia 6 (enam) tahun, dan dalam umur 9 (sembilan) tahun telah digaulinya. Hal ini diakui sendiri oleh Aisya ummi al Mukminin dalam hadith:

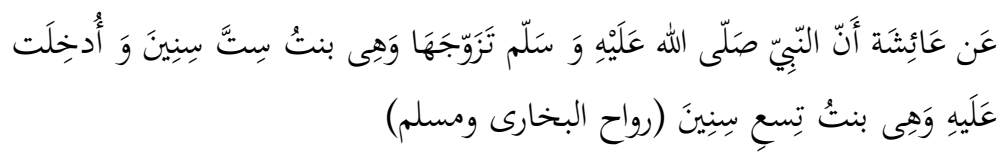

Dari Aisyah bahwa Nabi saw menikahinya saat dia berusia enam tahun dan bercampur dengannya saa dia berusia sembilan tahun (HR Al Bukhari dan Muslim).

Hadith tentang usia Aisyah saat dinikahi oleh Nabi Muhammad yang diriwayatkan oleh Bukhari dan Muslim hanya bersifat khabariyah atau kabar belaka tentang perkawinan Nabi. Dalam hadis tidak dijumpai khithab (pernyataan), baik berupa kbitab al thalab yang mesti diikuti ataupun khitab al-tark supaya ditinggalkan. Dengan demikian, pernyataan usia yang ada dalam hadith diatas tidak dapat disimpulkan sebagai pernyataan batas usia terendah keolehan melangsungkan pernikahan bagi kaum perempuan dan kaum pria. Karena baas usia untuk menikah dapat dianggap suatu rahmat.

Menurut fukaha, kedewasaan itu dapa ditetapkan berdasarkan tanda-tanda fisik yang menunjukkan bahwa seseorang itu telah mampu untuk menikah, seperti telah mengalami haid bagi wanita 
dan mengalami mimpi seksual bagi laki-laki, karena pengalamanpengalaman tersebut menunjukkan bahwa mereka telah mampu menikah dalam pengertian fisik.

\section{Pencegahan Perkawinan Pada Usia Anak}

Pencegahan merupakan suatu proses, cara, menahan perbuatan untuk tidak melakukan sesuatu, pencegahan dalam hal ini adalah agar tidak terjadi perkawinan pada usia anak.39 Usia anak yang dimaksud dalam Perbup Gunungkidul Nomor 36 Tahun 2015 tentang Pencegahan Perkawinan Pada Usia Anak ini adalah batas usia anak yang berlaku menurut undang-undang.

Pencegahan Perkawinan Pada Usia Anak adalah upaya-upaya yang berupa kebijakan, program, kegiatan, aksi sosial, serta upayaupaya lainnya yang dilakukan oleh pemerintah daerah, orangtua, anak, masyarakat dan semua pemangku kepentingan dalam rangka mencegah terjadinya perkawinan pada usia anak di Kabupaten Gunungkidul.40

\section{Implementasi Peraturan Bupati Gunungkidul Nomor 36 Tahun 2015 Tentang Pencegahan Perkawinan Pada Usia Anak Dalam Perspekif Maslahah Mursalah}

Hukum Islam menempatkan lembaga perkawinan dalam sebuah bingkai mulia sebagai bentuk ikatan sakral antara seorang laki-laki dengan seorang perempuan dengan tujuan menjadikan keluarga yang sakinah, mawaddah, warahmah. Hal ini bisa kita lihat dari petunjuk Al Quran yang melukiskan betapa lembaga perkawinan menjadi sangat penting kedudukannya di dalam hubungan kekeluargaan.

Perkawinan dikatakan sangat sakral sebab tidak hanya menyatukan dua hati, namun juga menyatukan dua keluarga sehingga ukhuwah Islamiyah akan semakin luas serta semakin kuat. Perkawinan menjadi sangat penting karena selain dapat menjaga kesucian manusia dari perbuatan zina yang bisa menjerumuskan ke lembah terhina secara kognitif adiktif dalam konteks psikologi yang

39 Perhatikan Pasal 1 Angka 5 Bab I Perbup Gunungkidul Nomor 36 Tahun 2015 tentang Pencegahan Perkawinan Pada Usia Anak

40 Perhatikan Pasal 1 Angka 6 Bab I Perbup Gunungkidul Nomor 36 Tahun 2015 tentang Pencegahan Perkawinan Pada Usia Anak 
akan dialaminya, juga akan jatuh pada lembah terdalam atas apa yang telah diperingatkan oleh Allah Swt.

Faktanya di Indonesia banyak sekali perkawinan yang dianggap masih menjadi media kebutuhan biologis semata dalam kurun waktu sementara secara sah, bisa kita lihat bahwa banyak sekali pernikahan yang dilangsungkan saat calon mempelai pria maupun calon mempelai wanta usianya masih muda atau dikatakan belum dianggap dewasa menurut undang-undang, penyebabnya antara lain adalah faktor lingkungan adat masyarakat yang telah melekat, atau mayoritas dari mereka telah melakukan hubungan intim sebelum menikah, sehingga penyebabnya dari pernikahan yang telah dilangsungkan itu yakni ketika saat proses kehamilan dan proses melahirkan kebanyakan si calon ibu belum dikatakan siap secara biologis maupun psikologis.

Selain itu fakta lain yang banyak ditemukan pada lembaga peradilan yang mengurusi perceraian (Pengadilan Agama) di Indonesia, bahwa menurut data yang dilansir oleh Badan Pusat Statistik (BPS) dalam "Statistik Indonesia 2018" sebuah publikasi kompilasi data statistik tahunan di Indonesia, jumlah seluruh kasus perceraian yang terjadi di Indonesia pada tahun 2017 adalah sebanyak 374.516 kasus, angka tersebut sudah termasuk pasangan suami isteri usia muda yang melakukan perceraian. 41

Mengerucut dari hal diatas mengambil salah satu data provinsi di Indonesia yakni DI Yogyakarta sendiri dalam catatan Badan Pusat Statistik ditemukan sebanyak 5.220 kasus jumlah talak dan cerai pada tahun 201742, tentu merupakan suatu angka yang tinggi dengan perbandingan ratio skala wilayah yang terbagi dengan 5 wilayahnya yakni; Kabupaten Bantul, Kabupaten Gunungkidul, Kabupaten Kulon Progo, Kabupaten Sleman, dan Kota Yogyakarta sendiri.

Kabupaten Gunungkidul merupakan salah satu kabupaten di DIY dengan jumlah penduduk cukup besar. Berdasarkan hasil estimasi Sensus Penduduk 2010 jumlah penduduk Kabupaten Gunungkidul tahun 2012 berjumlah 680.406 jiwa yang terdiri dari

41 BPS, “Statistik Indonesia 2018”, dalam smartlgal.id diakses 10 Mei 2019.

42 Dikutip dari Data Sensus Badan Pusat Statistik Online pada tanggal 3 Mei pukul 19.36 WIB. 
laki-laki sebanyak 328.878 jiwa dan perempuan sebanyak 351.528 jiwa.

Kabupaten Gunungkidul juga telah membuat catatan penting mengenai sebab akibat kasus-kasus yang berkaitan dengan perkawinan pada usia anak, berdasarkan data yang diperoleh dari hasil wawancara bersama Ketua DPRD Kabupaten Gunungkidul Bapak Demor Kursiswanto yang mengutip data Badan Pemberdayaan Perempuan dan Masyarakat (BPPM) DIY, tercatat terdapat 109 kasus pernikahan dini yang terjadi di Gunungkidul pada tahun 2015, data ini diafirmasi oleh catatan laporan perkara yang diterima menurut jenis pekara dispensasi kawin pada Pengadilan Agama Wonosari Tahun 2015.

Menurut Rumi Hayati Kepala Bidang Badan Pemberdayaan Masyarakat, Perempuan, dan Keluarga Berencana Kabupaten Gunungkidul, dari banyaknya kasus pernikahan dini yang tercatat dalam laporan perkara Pengadilan Agama Wonosari Tahun 2015 ini disebabkan oleh beberapa faktor; yakni asumsi apabila sang anak ketika beranjak remaja menuju dewasa memiliki keadaan fisik menyerupai orang dewasa lalu tidak dinikahkan akan dipandang sebagai anak yang boros pada fisik, orang jawa menyebut dan mengaitkannya dengan sebutan perawan tuwo (perawan tua) untuk perempuan, dan joko kasep (jejaka tua) untuk laki-laki, ada lagi kebiasaan yang unik yakni menyegerakan anak untuk dinikahkan supaya beban perekonomian bisa berkurang, singkatnya faktor ekonomi. Sehingga perkawinan anak telah terjadi membudaya begitu saja tanpa memikirkan sebab akibat yang akan ditanggung kedepannya.43

Rumi Hayati menambahkan bahwa akibat dari tingginya angka kematian bayi yang terjadi di Kabupaten Gunungkidul selama Tahun 2015 terakhir seimbang dengan banyaknya penikahan anak ini. Mengapa demikian? Karena faktanya kematian bayi yang terjadi rata-rata memang disebabkan oleh pasangan yang menikah di usia anak, tapi si calon ibu sendiri dikatakan memang belum siap secara biologis, sehingga kemungkinan saat masa mengandung atau melahirkan juga si bayi akan mengalami sesuatu yang dapat

43 Rumi Hayati, Kabid BPMPKB Kab. Gunungkidul, Wawancara, BPMPKB Gunungkidul 11 Desember 2018. 
membahayakan nyawanya, mulai dari cacat fisik hingga berujung kematian. Dari sinilah Bupati Kabupaten Gunungkidul bersamasama dengan UPT pemerintahannya yang konsens atau membidangi hal ini berusaha mencoba menangkal keresahan masyarakat dengan melakukan upaya untuk menekan angka kematian bayi serta pernikahan anak dengan harapan terwujudnya Kabupaten Gunungkidul sebagai Kota Layak Anak (KLA).

Alasan lain selain faktor realita sosial yakni alasan perundangundangan, memang secara hirarki peraturan Bupati akan kalah dengan peraturan Perundang-undangan, bisa kita lihat ada UU Perkawinan Nomor 1 Tahun 1974 dan lain-lain, tapi memang alasan sosial ini menimbulkan perhatian khusus, maka peraturan ini juga memang sengaja dibuat secara khusus, bukankah sudah jelas Lex Specialis Derogat Lex Generalis, atau dalam fikih sesuatu yang 'am (umum) bisa dianulir dengan sesuatu yang khas (khusus).

Dari berbagai ikhtiar dan dukungan seluruh elemen masyarakat Kabupaten Gunungkidul, kini lahirlah Peraturan Bupati Gunungkidul Nomor 36 Tahun 2015 Tentang Pencegahan Perkawinan Pada Usia Anak ini, seluruh UPT di Kabupaten Gunungkidul yang memiliki bidang ketugasan terkait dengan perempuan dan anak sama-sama saling mensosialisasikan adanya Perbup ini, tidak serta merta tugas sosialisasi ini hanya diemban oleh pegawai pemerintah, anak-anak yang beranjak remaja menuju dewasa turut menyemarakkan adanya Perbup ini melalui forum anak, serta kegiatan sosial lainnya. Orang tua dan masyarakat pun juga turut berpartisipasi, yakni dengan mencoba memulai kembali memberikan arahan dan pengertian kepada lingkungannya masingmasing.

Sesungguhnya pemerintah telah menyiapkan beberapa upaya preventif untuk menekan angka perceraian yang cukup tinggi, nomenklatur program khusus calon pengantin yang dimiliki Kementrian Agama seperti kegiatan sekolah pranikah, kuliah pranikah, seminar pranikah, pelatihan pranikah, kursus calon pengantin dilakukan demi membangun kehidupan rumah tangga yang lebih bahagia, harmonis, dan sejahtera. Akan tetapi pada praktiknya program-program pemerintah tersebut banyak yang tidak berjalan secara efektif, program-program yang dicanangkan 
tidak terlaksana secara terstruktur, sistematis, dan massif. Tapi tentu berbeda dengan Peraturan Bupati Nomor 36 Tahun 2015 Tentang Pencegahan Perkawinan Pada Usia Anak ini. Kebijakan yang memang benar-benar menjadi salah satu prioritas program kerja Kabupaten ini justru banyak meraih penghargaan, bahkan banyak daerah lain yang berusaha melakukan studi banding adanya Perbup ini.

Ditinjau dari perspektif maslabah mursalah, Peraturan Bupati Gunungkidul Nomor 36 Tahun 2015 Tentang Pencegahan Perkawinan Pada Usia Anak ini merupakan satu kebijakan 'amr (pemimpin) dimana didalamnya wujud dari pengimplementasian maqasid syariah, yakni terwujudnya tujuan syari yang bersifat daruri (pokok).

Menurut Wahbah Az-Zuhaili dalam kitab Usul Al-Fiqh AlIslami mendefinisikan maslahah mursalah sebagai berikut:

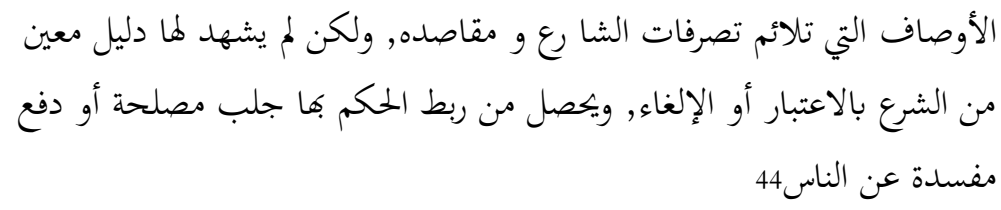

"sifat-sifat yang selaras dengan tindakan dan tujuan tasyri' tetapi tidak ditemukan dalil khusus yang mensyariatkannya, dan dari perhubungan hukum dengan sifat tersebut maka akan tercapai keMaslahahan dan bisa menolak kerusakan pada manusia"

Dengan kata lain, kategori maslabah jenis ini berkaitan dengan maqasid al-syariah, yaitu agar terwujudnya tujuan syaria yang bersifat daruri (pokok).

Selain itu, Peraturan Bupati Gunungkidul Nomor 36 Tahun 2015 Tentang Pencegahan Perkawinan Pada Usia Anak dapat dikatakan termasuk dalam kategori maslahah mursalah, dikarenakan dalam kenyataannya Peraturan Bupati Gunungkidul Nomor 36 Tahun 2015 Tentang Pencegahan Perkawinan Pada Usia Anak ini tumbuh dan berkembang seiring dengan perkembangan masyarakat

44 Wahbah Az-Zuhaili, Usul Al-Figh Al-Islami, (Darul Fikr, 1987), 757. 
Islam maupun masyarakat non Islam yang dipengaruhi oleh kondisi sosial dan lainnya di Kabupaten Gunungkidul.

Dari segi tingkatannya sendiri, Peraturan Bupati Gunungkidul Nomor 36 Tahun 2015 Tentang Pencegahan Perkawinan Pada Usia Anak memang termasuk dalam tingkatan maslahah daruriyat, karena peraturan tersebut memang menjadi sesuatu yang asasi (pokok), yakni melindungi dan menjamin kelestarian agama (bifdh al-din), melindungi jiwa (bifdh al-nafs), melindungi akal (bifdh al-aqh), melindungi keturunan (bifdh al-nash), dan melindungi harta (bifdh almal).

Maslahah mursalab adalah sesuatu perbuatan atau lain-lain yang dapat mendorong kepada kebaikan manusia, bermanfaat bagi manusia, serta menghindari suatu kerusakan pada manusia itu. Syarat bisa dikatakan maslahah mursalah sendiri memang sesuatu (peraturan) itu salah satunya bukan berupa suatu hal yang samarsamar, dan bersifat umum. Bisa dipastikan Peraturan Bupati Gunungkidul Nomor 36 Tahun 2015 Tentang Pencegahan Perkawinan Pada Usia Anak ini adalah suatu kebijakan, program, bentuk aksi yang nyata selain bukti fisik secara tinta hitam diatas keras putih, upaya-upaya seluruh elemen masyarakat Gunungkidul yang saling bahu membahu merealisasikan aturan ini tidak mungkin tidak bisa dikatakan masuk dalam syarat maslahah mursalah. Selain itu peraturan ini berlaku bagi seluruh umat beragama maupun umat non beragama yang ada di Gunungkidul, jadi tidak hanya berlaku kepada umat muslim saja.

Bukti lain sebagai bahan tambahan pertimbangan peraturan ini termasuk dalam maslahah mursalab adalah hasil wawancara bersama Bapak Drs. H. Barwanto, SH. MH. Berdasarkan data laporan perkara yang diputus pada Pengadilan Agama Wonosari Gunungkidul45, tercatat46 tahun 2015 terdapat 109 perkara dispensasi kawin, tahun 2016 terdapat 85 perkara dispensasi kawin, tahun 2017 terdapat 65 perkara dispensasi kawin, dari sini kita bisa melihat bahwasanya hasil nyata dari dampak adanya Peraturan Bupati Gunungkidul Nomor 36 Tahun 2015 Tentang Pencegahan

45 Barwanto, Humas PA Wonosari, Wawancara, Pengadilan Agama Wonosari Kab. Gunungkidul, 10 Desember 2018.

46 Lihat tabel 1 dan tabel 2. 
Perkawinan Pada Usia Anak ini membuat cita-cita masyarakat dan pemerintah Gunungkidul untuk menekan jumlah pernikahan anak berhasil, sehingga bisa dipastikan kematian bayi akibat perkawinan yang dilangsungkan oleh pasangan muda-mudi akan menurun.

Tabel 1, laporan perkara dispensasi kawin yang diterima menurut jenisnya47

\begin{tabular}{|c|c|c|c|}
\hline Tahun & 2015 & 2016 & 2017 \\
\hline Jumlah perkara & 109 & 85 & 67 \\
\hline
\end{tabular}

Tabel 2, laporan perkara dispensasi kawin yang diputus48

\begin{tabular}{|c|c|c|c|}
\hline Tahun & 2015 & 2016 & 2017 \\
\hline Jumlah perkara & 109 & 79 & 67 \\
\hline
\end{tabular}

Berbicara mengenai peraturan yang dibuat Bupati Gunungkidul sebagai pejabat yang memiliki otoritas tertinggi di Kabupaten Gunungkidul, merupakan kebijakan yang tidak bisa lahir begitu saja, tentu dengan pertimbangan dan pengukuran yang sangat matang, serta mengikut sertakan peran-peran UPT yang terkait dalam membidangi hal ini, tentu pada akhirnya yang menjadi tujuan adalah sisi kebaikan dan kemanfaatan seluruh masyarakat Gunungkidul, menurut Qaidah Fiqiyah:

$$
\text { تصرف الامام على الرعية منوط بالمصلح }
$$

"kebijaksanaan Imam/kepala Negara terhadap rakyat itu harus dihubungkan dengan kemalahatan"

At-tasarruful Imam 'Ala Al-Ra'iyyah Manutun Bi Al-Maslabah sebagaimana telah dijelaskan di atas bahwa kaidah ini merupakan

47 Panitera Pengadilan Agama Wonosari, Laporan Perkara Yang Diterima Menurut Jenisnya Pada PA Wonosari Tabun 2015, 2016, dan 2017.

48 Panitera Pengadilan Agama Wonosari, Laporan Perkara Yang Diputus Pada PA Wonosari Tabun 2015, 2016, dan 2017. 
kaidah (fikih) yang mempunyai aspek horizontal, seperti peraturan ini dalam implementasinya memerlukan hubungan antara seorang pemimpin dengan masyarakat atau rakyat yang dipimpin.

Ada beberapa kebaikan dan kemanfaatan yang ditimbulkan dari Peraturan Bupati Gunungkidul Nomor 36 Tahun 2015 Tentang Pencegahan Perkawinan Pada Usia Anak, diantaranya:

1. Perspektif Psikologis, peraturan ini akan memberi perlindungan dan harapan dimana anak akan lebih siap secara mental sebelum menerima kenyataan menaungi bahtera rumah tangga kedepannya. Anak yang dalam usia remaja sedang dalam masa pencarian identitas akan lebih mengeksplorasi potensinya, sehingga beban akan menjadi orang dewasa bahkan menjadi orang tua ini bisa lebih siap diembannya kelak setelah masa pencarian jati diri dirasa cukup sebelum melangsungkan jenjang pernikahan.

2. Perspektif Kesehatan, adanya peraturan ini tentu sangat memperhatikan tumbuh kembangnya anak dalam masa produksi dengan pertimbangan bahaya dan resiko seksual. Selain itu, peraturan ini sangat mengistimewakan wanita sebagai calon ibu, pertimbangan kesehatan rahim yang menjadi prioritas kesiapaan sebagai calon ibu, mengingat resiko kematian calon ibu juga sangat diperhatikan, apalagi usia rahim secara biologis bagi anak memang belum dikatakan secara usia yang matang untuk mengandung jabang bayi.

3. Perspektif Pendidikan, pada isi peraturan ini juga sangan memprioritaskan hak anak untuk tetap mendapatkan harapan yang baik, yakni mendapatkan hak pendidikan yang berjenjang sesuai dengan anjuran pemerintah yang berlaku, yakni 12 tahun wajib belajar, pemerintah telah mengupayakan apabila ada alasan ekonomi sehingga anak tidak bisa melanjukan pendidikan, pemerintah akan mencari jalan sperti program-program beasiswa.

4. Perspektif Ekonomi, sudut pandang ini memang sedikit menuai kontroversi bagi masyarakat Gunungkidul pada awal diberlakukannya peraturan ini, upaya preventif pemerintah yakni melakukan pembinaan kepada anak melalui kegiatan-kegiatan sosial supaya bakat minat serta potensi anak bisa menjadi 
pedoman anak untuk memiliki masa depan yang diharapkan kedepannya, contoh kegiatan sosial ini seperti membentuk forum anak.

5. Perspektif Sosial Budaya, tidak dapat dipungkiri adat istiadat akan menjadi garis terdepan yang paling menentang adanya perbup ini, alih-alih menstabilkan problema sosial, justru peraturan ini mendapat pertentangan pada awalnya, namun inilah tantangannya. Dengan tekad yang kuat, seluruh elemen masyarakat pemerhati realita sosial yang ada saling bahu membahu mewujudkan mimpi Kabupaten Gunungkidul sebagai daerah yang layak anak.

Rumi Hayati mempertegas kebaikan dan manfaat adanya peraturan ini yakni, aset generasi penerus bangsa memang harus dilindungi dan dikembangkan, semaksimal mungkin menumbuh kembangkan potensi sehingga tidak terputus ditengah jalan, kalau pasangan muda mudi menikah tentu sangat susah bahkan bisa dikatakan tidak mungkin akan melanjutkan sekolah, disinilah peraturan ini sangat berperan. Selain itu perubahan usia pernikahan pada usia anak menurun dengan didukung data yang konkret, tentu hal ini juga turut diikutinya angka meninggal pada bayi juga menurun. Seiring perkembangan zaman yang semakin melaju barang kali ada hal-hal yang tidak sesuai dengan perkembangan zaman maka tidak menutup kemungkinan peraturan ini akan direvisi, kedepannya peraturan ini tetap dilanjutkan.

Dalam pengakuan Rumi Hayati sendiri, setelah melihat hasil yang didapat Kabupaten Gunungkidul, banyak sekali UPD didalam DIY dan diluar DIY datang ke Gunungkidul untuk melihat proses peraturan ini dan pelaksanaannya.

Bapak Demor Kursiswanto yang menjabat sebagai Ketua DPRD Kabupaten Gunungkidul mengatakan bahwa peraturan ini membawa suatu kemanfaatan yang nampak, dengan adanya ketegasan dari seluruh pelbagai pihak yang terlibat, maka akan menjamin kesehatan ibu, anak, serta menjamin tingkat emosional kedua pasangan. Selain itu beliau menegaskan bahwa apabila pernikahan dilangsungkan pada usia (biologis, psikologis, dll) yang tepat, maka keduanya (calon mempelai) bisa memiliki pola pikir yang lebih dewasa ketika menapaki rumah tangga dalam menyikapi 
bahtera yang akan terjadi dikemudian harinya, seperti bahtera perekonomian. Beliau juga berpendapat peraturan ini bisa manjadi percontohan daerah-daerah lain sekitar Kabupaten Gunungkdiul.49

Menelisik lebih jauh sisi kebaikan dan kemanfaatan adanya peraturan ini, murut Bapak Sugito salah seorang asli Gunungkidul desa Pulegundes yang berhasil saya wawancarai juga mengatakan bahwa sekarang sudah mulai jarang ditemukan adanya pernikahan pada usia anak, beliau yang terbilang sebagai masyarakat adanya karena memasuki usia 51 th ini sangat mendukung adanya peraturan ini, besar harapan beliau peraturan ini tetap dilaksanakan.50

Berbeda dengan Velin Ulvandhia, mahasiswa Universitas Gadjah Mada asli Gunungkidul desa Paliyan mengatakan bahwa peraturan ini masih belum masuk didesanya, mendengar kabar adanya peraturan ini, Velin sangat antusias karena dianggapnya sangat baik adanya peraturan ini, karena Bupati memiliki atensi kepada anak, sehingga bisa mengurangi dampak negatif seperti penyakit kelamin yang dialami anak Gunungkidul selama yang diketahuinya. Velin berharap pemerintah segera mensosialisasikan dan melaksanakan kegiatan sosial demi terwujudnya pemerataan peraturan ini, serta peraturan ini juga bisa dijadikan percontohan ke daerah-daerah lain.51

Hingga pada akhirnya Peraturan Bupati Gunungkidul Nomor 36 Tahun 2015 Tentang Pencegahan Perkawinan Pada Usia Anak yang terbukti dampaknya bisa menimbulkan kebaikan dan mendatangkan manfaat memang sangat perlu dilaksanakan dan dilestarikan, kedepannya peraturan ini bisa dijadikan role model bagi daerah-daerah lain di Indonesia.

\section{Penutup}

Implementasi pencegahan perkawinan pada usia anak adalah upaya-upaya serta usaha-usaha menahan agar tidak terjadi perkawinan pada usia anak berupa kebijakan, program, kegiatan,

49 Demor Kursiswanto, Ketua DPRD Kabupaten Gunungkidul, Wawancara, Kantor DPRD Kab. Gunungkidul, 6 Desember 2018.

50 Sugito, Warga Gunungkidul, Wawancara, Sadranan Pulegundes Kab. Gunungkidul, 9 Desember 2018.

51 Velin Ulvandhia, Mahasiswa UGM, Wawancara, Gedung Perpustakaan Sekolah Vokasi Universitas Gadjah Mada, 11 Desember 2018. 
aksi-aksi sosial yang dilakukan oleh pemerintah daerah, orangtua, anak, masyarakat, dan semua pemangku kepentingan. Perkawinan pada usia anak ditegaskan dalam Perbup Gunungkidul Nomor 36 Tahun 2015 Tentang Pencegahan Perkawinan Pada Usia Anak yakni yang belum berusia 18 (delapan belas) tahun, atau batas usia yang tecantum secara yuridis baik menurut undang-undang maupun peraturan lainnya.

Maslahah Mursalah dari implementasi Perbup Gunungkidul Nomor 36 Tahun 2015 Tentang Pencegahan Perkawinan Pada Usia Anak yakni: Maslahah dharuriyyah, dimana peraturan ini telah melindungi dan menjamin kelestarian agama (bifz ad-din) dengan menghindarkan perzinahan, melindungi jiwa (bifz al-nafs) dengan menurunnya angka perceraian pasangan anak, melindungi akal (bifz al-aqD dengan terjamin dan terfasilitasinya pendidikan sehingga mampu open minded mengenai resiko menikah usia dini, melindungi keturunan (hifz al-nas) dengan menurunnya angka kematian bayi, dan melindungi harta (bifz, al-mal) dengan pembinaan pemberdayaan anak mengenai perekonomian. Maslabah bajiyyah, peraturan ini menjawab persoalan yang dibutuhkan manusia untuk menghilangkan kesulitan dan kesusahan yang dihadapi. Maslahah tabsiniyyah, dimana peraturan ini telah memelihara kebagusan dan kebaikan budi pekerti serta keindahan sosial budaya, tahun ke tahun masyarakat adat mulai memahami maksud adanya peraturan ini.

Peraturan ini bisa dijadikan percontohan untuk ditiru dan diterapkan oleh daerah di sekitarnya baik secara skala dalam provinsi maupun skala luar provinsi se-Indonesia. Mengingat, dampak kebaikan dan kemanfaatan adanya peraturan ini sangat berdampak bagi kehidupan masyarakat, utamanya masyarakat Kabupaten Gunungkidul.

\section{Daftar Pustaka}

Abdurrahman, Kompilasi Hukum Islam di Indonesia cet ke-4 Jakarta: Akademia Pressindo, 2010.

Ahmad Arif Masdar Hilmy, Skripsi -- UIN Sunan Ampel, Surabaya, 2018.

Aplikasi Maktabah Syamilah, Kitab Nikah Shobih Bukhori.

Barwanto, Humas PA Wonosari, Wawancara, Pengadilan Agama Wonosari Kab. Gunungkidul, 10 Desember 2018.

BPS, "Statistik Indonesia 2018”, dalam smartlegal.id diakses 10 Mei 2019. 
Data Sensus Badan Pusat Statistik Online pada tanggal 3 Mei pukul 19.36 WIB.

Departemen Agama Republik Indonesia, Al-Qur'an dan Terjemahannya Jakarta: Toha Putra Semarang, 1989.

Demor Kursiswanto, Ketua DPRD Kabupaten Gunungkidul, Wawancara, Kantor DPRD Kab. Gunungkidul, 6 Desember 2018.Sutomo, et al., Menggugat Stagnasi Pembaruan Hukum Islam di Indonesia, Yogyakarta: UII Press, 2016.

Imam Musbikin, Qawa'id al Fiqhiyyah, Jakarta: RajaGrafindo Persada, 2001. Kementerian Agama RI, "UU Nomor 1 Tahun 1974 tentang Perkawinan”, dalam https://kemenag.go.id-file-dokumen, diakses pada 22 Oktober 2018.

Moh Ali Wafa, "Telaah Kritis Terhadap Perkawinan Usia Muda Menurut Hukum Islam" dalam Jurnal AHKAM, No 2 2017.Nasiri, Kapita Selekta Perkawinan, Cilacap: Ihya Media, 2016.

Muhammad Yunus, Kamus Arab Indonesia, Jakarta: Yayasan Penyelenggaraan Penerjemah dan Penafsir al-Quran, 1973.

Panitera Pengadilan Agama Wonosari, Laporan Perkara Yang Diterima Menurut Jenisnya Pada PA Wonosari Tabun 2015, 2016, dan 2017.

Panitera Pengadilan Agama Wonosari, Laporan Perkara Yang Diputus Pada PA Wonosari Tabun 2015, 2016, dan 2017.

Perbup Gunungkidul Nomor 36 Tahun 2015 tentang Pencegahan Perkawinan Pada Usia Anak

Romli SA, Pengantar Ilmu Usul Fiqih Metodologi Penetapan Hukum Islam, Depok: Kencana, 2017Rumi Hayati, Kabid BPMPKB Kab. Gunungkidul, Wawancara, BPMPKB Gunungkidul 11 Desember 2018.

Sjarief Sukandy, Tarjamah Bulughul Maram Bandung: Al-Ma'arif, 1995.

Sugito, Warga Gunungkidul, Wawancara, Sadranan Pulegundes Kab. Gunungkidul, 9 Desember 2018.

Totok Jumantoro, Kamus Ilmu Usul Fikih, Jakarta: Sinar Grafika Offset, 2005.

Velin Ulvandhia, Mahasiswa UGM, Wawancara, Gedung Perpustakaan Sekolah Vokasi Universitas Gadjah Mada, 11 Desember 2018.

Wahbah Az-Zuhaili, Usul Al-Fiqh Al-Islami, Darul Fikr, 1987.

Witanto, Hukum Keluarga Hak dan Kedudukan Anak Luar Kawin Pasca Keluarnya Putusan MK Tenang Uji Materiil UU Perkawinan, Jakarta: Prestasi Pustaka, 2012.

Yusuf Hanafi, Kontroversi Perkawinan Anak di Bawah Umur Perspektif Fikih Islam, HAM Internasional, dan UU Nasional, Bandung: Mandar Maju, 2011. 
Muhammad Agung: Implementasi Peraturan Bupati..... 